УДК 633.17:631.559

DOI https://doi.org/10.32848/agrar.innov.2021.10.4

\title{
БІОЛОГІЗАЦІЯ ТЕХНОЛОГІЇ ВИРОЩУВАННЯ МІСКАНТУСУ ГІГАНТСЬКОГО НА БІОПАЛИВО
}

\author{
ДЕКОВЕЦЬ В.О. - аспіранТ \\ https://orcid.org/0000-0003-3557-5016 \\ Полтавський державний аграрний університет \\ кулик М.І. - доктор сільськогосподарських наук, професор \\ https://orcid.org/0000-0003-0241-6408 \\ Полтавський державний аграрний університет \\ ГАЛИЦьКА М.А. - кандидат сільськогосподарських наук, старший викладач \\ https://orcid.org/0000-0003-2579-0515 \\ Полтавський державний аграрний університет
}

Постановка проблеми. Енергетика як галузь виробництва розвивається дуже швидкими темпами, тому гарантування енергетичної безпеки та зниження антропогенного впливу енергетики на довкілля - важливе завдання сьогодення [1].

Поряд із цим застосування поновлювальних джерел енергії на основі розвитку біоенергетики, що базується на виробництві електричної та теплової енергії з різних видів біопалив рослинного походження, має значні перспективи розвитку як в Україні загалом, так і в регіонах. Виробництво та трансформація біомаси в різні види енергії здійснюється в три етапи: перший етап - це вирощування і збирання біомаси енергетичних культур, другий етап - це перетворення біомаси в біопаливо, третій етап - виробництво енергії з наступним постачанням споживачам [2].

Цю думку підтримують Л.М. Пронько, Т.В. Колесник, стверджуючи, що важливим аспектом біоенергетики $€$ використання поновлювальних джерел енергії, що дасть змогу забезпечити стабільне існування людства. Саме можливості їх використання у господарстві в останні роки надаються переваги, оскільки такий підхід дозволить забезпечити охорону навколишнього середовища [3].

Саме тому світова спільнота розглядає використання місцевих альтернативних джерел енергії як один із перспективних шляхів вирішення зростаючих проблем енергозабезпечення [4].

Очікується, що з усіх відновлюваних джерел енергії найбільший внесок у найближчій, особливо у короткота середньостроковій перспективі, буде отримано від рослинної біомаси. Паливо, отримане з енергетичних культур, не тільки потенційно поновлюване, але також досить схоже за походженням на викопне паливо (основою якого $€$ також біомаса) та може забезпечити пряму заміну. Визначено, що вирощування енергетичних культур та їх використання як сировини для виробництва біопалива в Україні - новий та перспективний напрям для розвитку бізнесу у сфері альтернативної енергетики. Сьогодні цей напрям альтернативної енергетики у державі перебуває на етапі розвитку [5].

Отже, враховуючи високий потенціал за врожайністю біомаси, її сталість та з урахуванням екології довкілля, вивчення біологізація технології вирощування міскантусу гігантського задля отримання біопалива має актуальне значення.
Аналіз останніх досліджень і публікацій.

В умовах Лісостепу України дослідження 3 розроблення біоенерґозберігаючих технологій вирощування міскантусу гігантського мають фрагментарний характер, а на малородючих землях цього регіону досліджень в цьому напрямі недостатньо. Відсутність експериментальних даних з оцінки впливу елементів біологізації на продуктивність міскантусу гігантського, їх чутливості до цих агротехнічних прийомів зумовлюють вибраний напрям дослідження. Поряд із наявними дослідженнями вивчення використання рослинами елементів живлення і строків сівби дає змогу удосконалювати енергозберігаючі технології вирощування.

Розробленню прийомів збільшення виробництва рослинної сировини міскантуса із застосуванням елементів біологізації технологій, у різні роки в Україні чимало уваги надавали М.В. Роїк, В.Л. Курило, Д.Б. Рахметов, В.А. Доронін, М.Я. Гументик, О.М. Ганженко та інші [10-18].

Сьогодні науковці інтенсивно вивчають і вдосконалюють технологію вирощування енергетичних культур. Тому поряд з агрономічно обґрунтованим менеджментом вирощування енергетичних культур актуальним та недостатньо вивченим питанням залишаються екологічні аспекти вирощування цих рослин на маргінальних землях [5].

Визначальними чинниками, що зумовлюють врожайність міскантусу гігантського, є біометричні показники рослин. Це підтверджується дослідженнями М.Я. Гументика та інших науковців [6], в яких визначено, що мінливість кількісних показників рослин пов'язана як із елементами технології вирощування, так і з погодними умовами вегетаційного періоду. При цьому не менш важливим фрактором $є$ видові особливості культури при багаторічному циклі вирощування: збільшення кореневої системи, відростання нових пагонів із сплячих бруньок, зростання висоти стеблостою тощо. Також, згідно 3 дослідженнями цього автора, встановлено значну ефективність сумісного вирощування проса прутоподібного і міскантусу гігантського [7].

Інші автори визначили, що для міскантусу гігантського можливо отримати врожайність біомаси за сухою речовиною на рівні 12-16 т/га (до 25,0 т/га), але при цьому необхідно дотримуватися усіх вимог до виконання технологічних операцій вирощування [8]. 
Інша колективна наукова праця розкриває особливості агротехнології вирощування, збирання та переробки біомаси міскантусу в Україні [9].

Результати досліджень українських та закордонних авторів свідчать про зацікавленість науковців у всебічному вивченні особливостей вирощування міскантусу задля отримання біопалива.

Мета статті. Метою дослідження $€$ визначення впливу різних способів вирощування на врожайність біомаси міскантусу гігантського в умовах центрального Лісостепу України.

Завдання дослідження полягало у визначенні впливу різних способів вирощування (одновидових - монокультура або сумісних із різними бобовими культурами) з урахуванням умісту органічної речовини у ґрунті на врожайність біомаси міскантусу гігантського сорту Гулівер, що слугувало основою для розроблення основ біологізації технології вирощування міскантусу гігантського для отримання біопалива.

Матеріали та методика досліджень. Дослідження проводилися протягом 2016-2020 рр. на баз Полтавського державного аграрного університету. Ґрунти дослідної ділянки - чорноземи типові, з умістом гумусу на рівні $3,4 \%$, вміст азоту - середній, фросфору і калію - підвищений (більше 0,6 г/кг ґрунту).

У дослідах була застосована рендомізація варіантів у межах кожного з чотирьох повторень експерименту згідно з методикою дослідної справи в агрономії [13].

Схема експерименту поєднувала вивчення таких чинників: фрактор А - вегетаційний рік (2016-2020рр.), фрактор Б - способи вирощування міскантусу гігантського: варіант 1 - одновидовий (контроль), варіант 2 - вирощування сумісно з багаторічним люпином (лат. Lupinus perennis L.), варіант 3 - вирощування сумісно 3 люцерною серповидною (лат. Medicago falcata L.), варіант 4 - вирощування сумісно з конюшиною червониою (лат. Trifolium pratense L.).

Агротехніка у дослідах здійснена згідно з рекомендаціями [14], застосування добрив та засобів захисту рослин не проводили.

Інтенсивність накопичення органічного вуглецю від рослинних решток під час вирощування енергетичних культур визначали оксидиметричним методом за ДСТУ 4289:2004 Якість ґрунту. Методи визначання органічної речовини. Попередньо підготовлену повітряно-суху, просіяну через сито пробу ґрунту масою 0,3 г та пемзу, яку використовували як контрольні («холості») проби, зважували з точністю 0,1 г на лабораторних аналітичних вагах загального призначення 4-го класу та поміщали в сухі термостійкі конічні колби місткістю $100 \mathrm{~cm}^{3}$. У кожну колбу з бюретки додавали по 25 мл 0,4 Н хромової суміші, після чого закривали скляними лійками діаметром не менше 4 см та круговими рухами перемішували вміст. Підготовлені таким чином всі проби ґрунту з окисником, а також контрольні проби вміщували у попередньо розігріту до $120^{\circ} \mathrm{C}$ шафу і витримували 20-30 хв. до закінчення процесу окиснення. Після охолодження зразків лійки ретельно обмивали дистильованої водою та проводили титрування $0,2 \mathrm{H}$ розчином солі Мора в присутності 3-5 крапель індикатора
0,2\% розчину френілантранілової кислоти до зміни його забарвлення.

Усі визначення проводилося в трьохразовій повторюваності. Масову частку вуглецю органічної речовини у відсотках (\%С орг $)$ розраховували за формулою:

$$
\% \mathrm{C}=\frac{(a-b) * \mathrm{H}_{1} * 0,0003 * 100}{m * \mathrm{H}_{0}},
$$

де:

C- вміст вуглецю, \%;

a - кількість розчину солі Мора, витраченого на титрування контрольної проби, см³;

$b$ - кількість розчину солі Мора, витраченого на титрування проби із ґрунтом, см³ $^{3}$;

$\mathrm{H}_{1}$ - нормальність робочого розчину солі Мора, $\Gamma^{*}$ екв/дм ${ }^{3}$;

$H_{0}$ - нормальність точного розчину солі Мора, $\Gamma^{*}$ екв/дм ${ }^{3}$.

0,0003 - грамовий еквівалент вуглецю, що відпові-

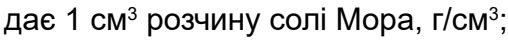

$m$ - наважка ґрунту, г;

100 - коефіцієнт перерахування, \%.

Облік врожайності біомаси здійснювали на час закінчення вегетації рослин шляхом зважування снопових зразків.

Статистичний обрахунок отриманих результатів із досліду здійснювали за допомогою дисперсійного аналізу з використанням програм Excel та Statistica.

Результати досліджень. Інтенсивність накопичення органічної речовини у ґрунті під час проведення досліджень змінювалася у широких межах і залежала від глибини шару ґрунту (рис. 1).

Під насадженнями міскантусу гігантського третього року вегетації депонування карбону в ґрунті варіювало в межах від 1,56 до $3,27 \%$ за середнього значення $2,11 \pm 0,46 \%$.

Встановлено, що надземна вегетативна маса (умовно волога) міскантусу гігантського змінювалася у межах від 21,5 до 51,0 т/га. 3 віком надземна продукція міскантусу статистично закономірно зростає $(p<0,05)$. У однорічному насадженні середня врожайність біомаси становить $21,0 \pm 4,2$ т/га та варіює у межах від 21,0 до 25,2 т/га. У 2-річному насадженні надземна біомаса сягає $33,4 \pm 2,5$ т/га та варіює у межах від 33,4 до 35,9 т/га. Вона вища, ніж надземна продукція 1-річного віку, на 15,6\%. У 3-річному насадженні надземна продукція становить 50,7 \pm 1,6 т/га та варіює у межах від 50,7 до 52,3 т/га. Вона вища, ніж надземна продукція 2-річного віку, на 18,4\% (рис. 2).

Встановлено, що врожайність міскантусу гігантського залежить від способу вирощування культури та мала значне варіювання за варіантами досліду. Найбільший урожай сухої маси $(7,4$ т/га) рослин першого року отримали на варіантах із люпином, істотно нижче - за сумісного вирощування з люцерною і конюшиною, відповідно 6,8 і 6,7 т/га (на одному рівні, в межах $\mathrm{HIP}_{05}$ ). На другий і тертій рік ця тенденція збереглася, але з істотно більшими показниками за врожайністю сухої біомаси, відповідно років - 12,4 т/га та 15,6 т/га на варіантах сумісного вирощування з люпином (рис. 3). 


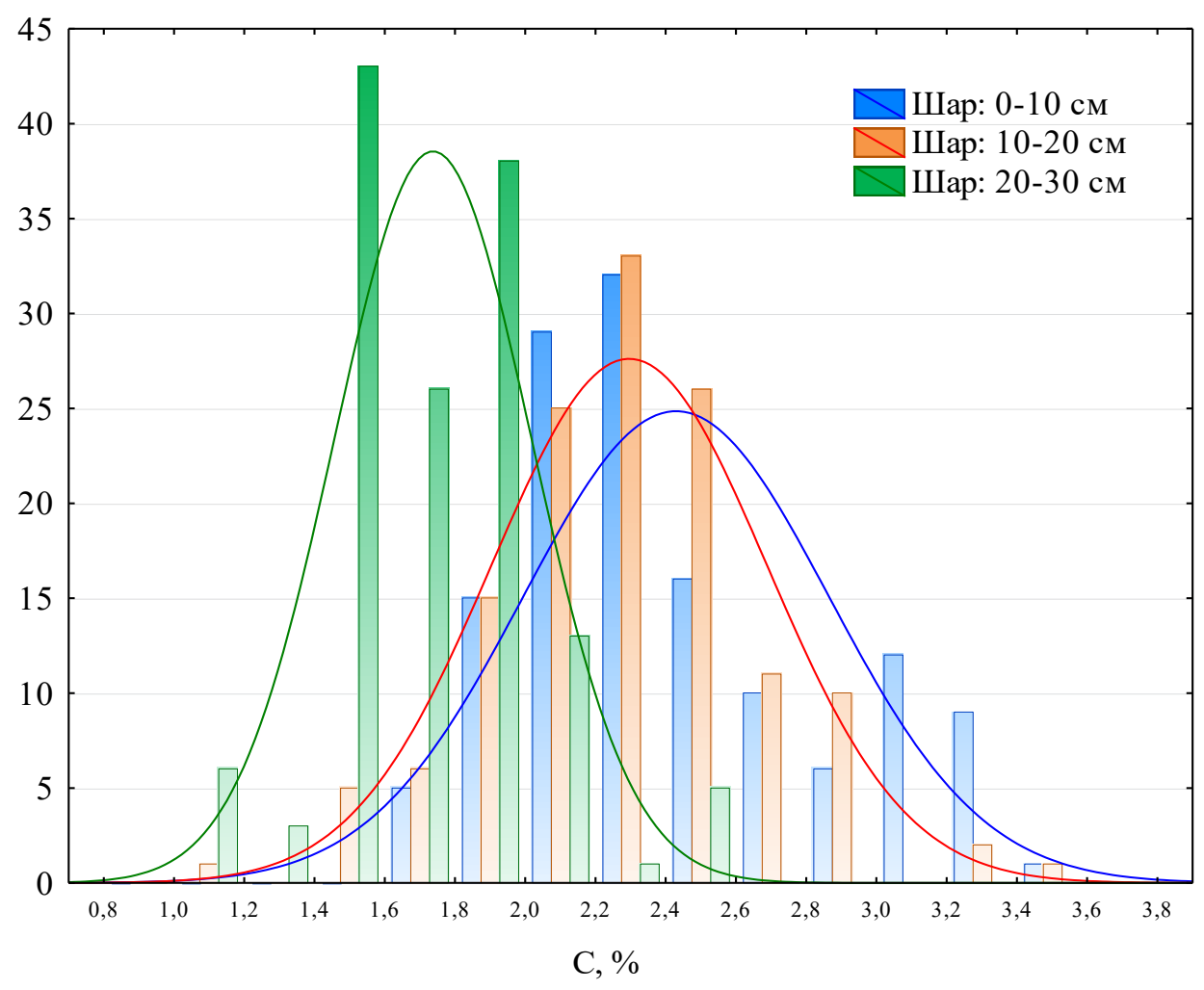

Рис. 1. Вміст органічної речовини у різних шарах ґрунту під насадженнями міскантусу гігантського, 2016-2020 рр.

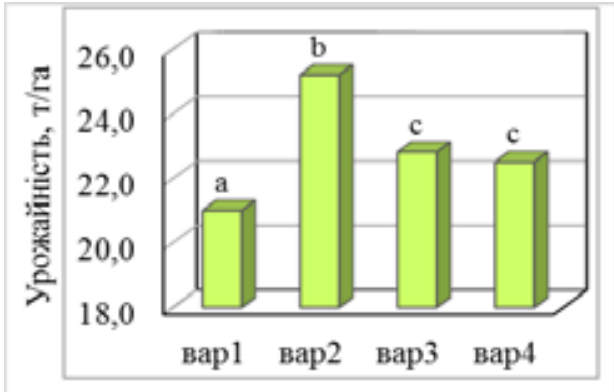

a

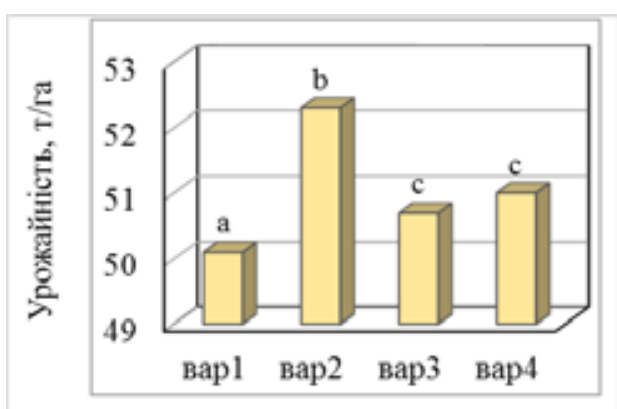

B

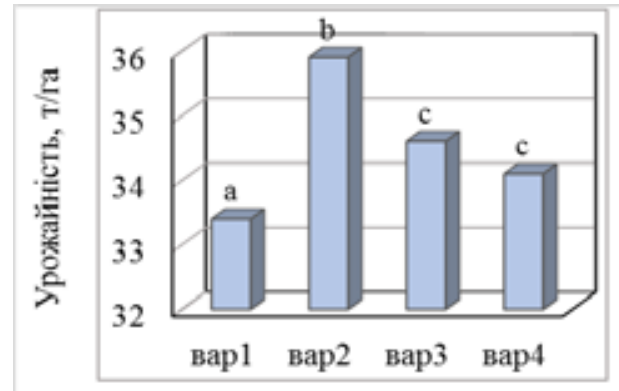

6

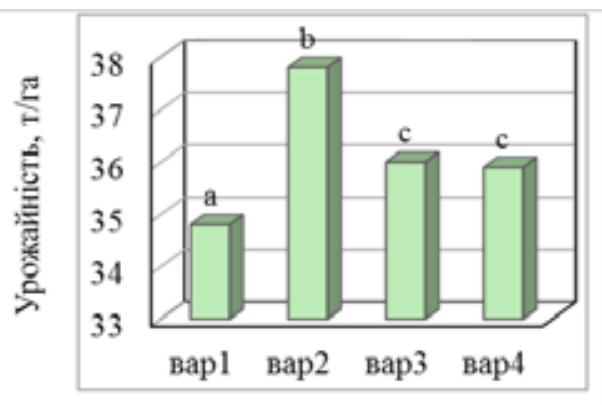

абв

Примітка: різні букви показують суттєві відмінності між варіантами досліду.

Рис. 2. Урожайність умовно вологої біомаси (т/га) міскантусу гігантського першого (а), другого (б) та третього (в) років вегетації, абв - середнє значення за роки вегетації, 2016-2020 рр. 


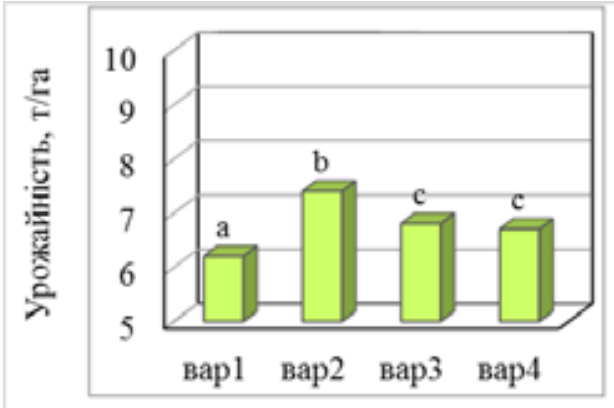

a

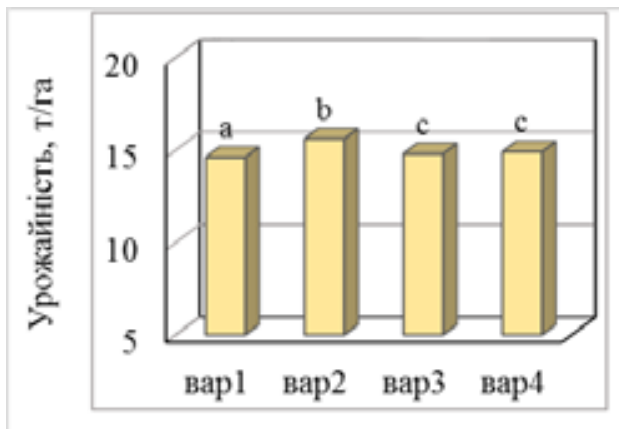

B

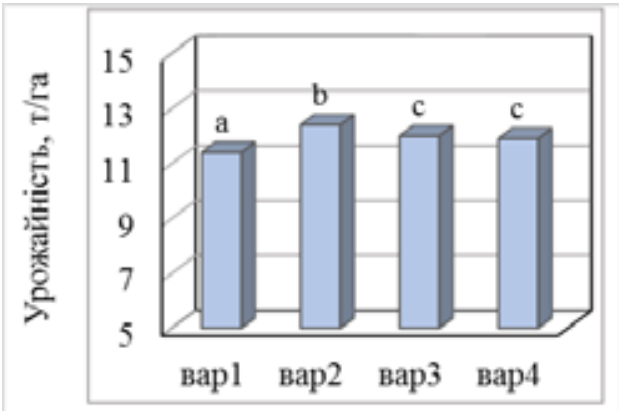

б

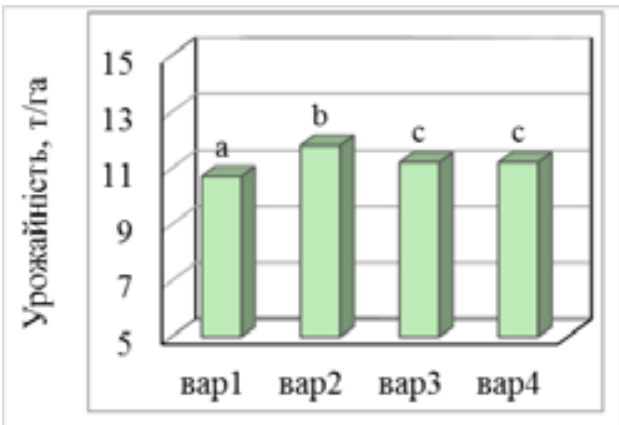

абв

Примітка: різні букви показують суттєві відмінності між варіантами досліду.

Рис. 3. Урожайність сухої біомаси (т/га) міскантусу гігантського першого (а), другого (б) та третього (в) років вегетації, абв - середнє значення за роки вегетації, 2016-2020 pp.

Отже, в середньому за роки досліджень встановлено, що порівняно з контрольними варіантами вирощування міскантусу гігантського сумісно разом із люпином збільшує врожайність на 1,1 т/га. На варіантах сумісного вирощування з люцерною і конюшиною отримали суттєво меншу прибавку врожаю, що виявилася рівнозначною $(0,5 \mathrm{т} /$ га).

Під час встановлення зв'язку між вмістом органічної речовини у ґрунті та врожайністю за сухою біомасою міскантусу визначено сильний вплив, що проявився на усіх варіантах досліду $(r \geq 0,7)$.

Висновки. Застосування сумісного вирощування міскантусу гігантського разом із бобовими культурами (люпин багаторічний) на третій рік вегетації сприяє збільшенню органічної речовини в ґрунті (до 3,27 \%) за одночасного зростання врожайності біомаси (до 15,6 т/га).

Перспективи подальших досліджень полягатимуть у встановленні впливу кількісних показників рослин на врожайність біомаси міскантусу у різновидових насадженнях енергоплантацій.

\section{СПИСОК ВИКОРИСТАНОÏ ЛІТЕРАТУРИ:}

1. Полянський О.С., Дьяконов О.В.,. Скрипник О.С та ін. Напрями розвитку альтернативних джерел енергії: акцент на твердому біопаливі та гнучких технологіях його виготовлення : монографія / за заг. ред. В.І. Д'яконова] ; Харків. нац. ун-т міськ. госп-ва ім. О.М. Бекетова. - Харків : ХНУМГ ім. О.М. Бекетова, 2017. С. 7.

2. Кулик М.І., Падалка В.В. Розвиток біоенергетики на основі рослинного енергетичного ресурсу (на прикладі Полтавської області). Управління стратегіями випереджаючого інноваційного розвитку : монографрія / за ред. к.е.н., доцента Н.С. Ілляшенко. Суми : Триторія, 2020. С. 109-118.

3. Пронько Л.М., Колесник Т.В. УМОВИ ТА ПЕРСПЕКТИВИ ВИРОБНИЦТВА І РЕАЛІЗАЦІЇ ПОНОВЛЮВАЛЬНИХ ДЖЕРЕЛ ЕНЕРГІЇ В УКРАЇНІ. Збірник наукових праць ВНАУ Серія: Економічні науки №1 (48) 2011. С. 185.

4. Пришляк Н.В. Потенційні можливості вирощування біоенергетичної сировини на виробництво твердого біопалива. Агросвіт. Вип. 1-2, 2021. C. 33-45. DOI: 10.32702/2306\&6792.2021.1-2.33

5. Директива Європейського Парламенту та ради 2009/28/€С від 23 квітня 2009 року про заохочення до використання енергії, виробленої з відновлювальних джерел. [Електронний ресурс] : Офіційний вісник Європейського союзу - URL: http://saee.gov. ua/documents/dyrektyva_2009_28.pdf

6. Гументик М.Я., Квак В.М., Замойський О.І., та ін. (2015) Вплив елементів механізованої технології вирощування на продуктивність біомаси міскантусу. Вісник Дніпропетровського державного аграрно-економічного університету. вип. 4, С. 50-54. 
7. Гументик М.Я. Особливості технології змішаного вирощування біоенергетичних злакових культур для виробництва біопалива. Біоенергетика. 2019. № 1. C. 16-18.

8. Caslin, B., Finnan J., Easson L. (2011). Miscanthus best practice guidelines Teagasc: Ecclesville Printing Services, V. 52 p. 91

9. Міскантус в Україні: колективна монографія. Колектив авторів. К.: ТОВ ЦП «Компрінт», 2019. $256 \mathrm{c}$.

10. Ганженко О.М. Технологія виробництва твердого біопалива з міскантусу / О.М. Ганженко, М.Я. Гументик, В.М. Квак // Біоенергетика. - 2015. № 2. С. 13-17. URL: http://nbuv.gov.ua/UJRN/Bioen_2015_26.

11. Способи підвищення виходу садивного матеріалу міскантусу гігантського / В.А. Доронін, В.В. Дрига, Ю.А. Кравченко, В.В. Доронін // Наукові праці Інституту біоенергетичних культур і цукрових буряків : зб. наук. праць / Ін-т біоенергет. культур і цукр. буряків, Нац. акад. аграр. наук України. К. : ФОП Корзун Д.Ю., 2018. Вип. 26. С. 11-20.

12. Міскантус в Україні : монографія / Роїк М. В. та ін. Київ : ФОП Ямчинський О.В., 2019. 256 с.

13. Роїк М.В., Курило В.Л., Гументик М.Я. та ін. Енергетичні культури для виробництва біопалива. Наукові праці Полтавської державної аграрної академії. 2010. Т. 7. С. 12-15.

14. Курило В.Л., Гументик М.Я., Квак В.М. Міскантус - перспективна енергетична культура для виробництва біопалива. Агробіологія. 2010. Вип. № 4 (80). С. 62-66.

15. Хіврич О.Б., Курило В.Л., Квак В.М. Енергетичні рослини, як сировина для біопалива. Пропозиція. 2011. Вип. № 6. С. 68.

16. Доспехов, Б.А. (1985). Методика полевого опыта. Москва: Колос. 416 с.

17. Ганженко О.М., Курило В.Л., Гументик М.Я., та ін. (2016) Методичні рекомендації з технології вирощування і переробляння міскантусу гігантського. К.: ТОВ «ЦП «Компринт», 40 с.

18. Рахметов Д.Б., Каленська С.М., Федорчук М.І., та ін. (2017) Методичні рекомендації з оптимізації технології вирощування міскантусу в різних грунтово-кліматичних зонах України. Видавничий центр «Колос»: ДВНЗ «Херсонський державний аграрний університет», $22 \mathrm{c}$.

\section{REFERENCES:}

1. Polianskyi O.S., Diakonov O.V., Skrypnyk O.S (2017). Napriamy rozvytku alternatyvnykh dzherel enerhii: aktsent na tverdomu biopalyvi ta hnuchkykh tekhnolohiiakh yoho vyhotovlennia : monohrafiia [Directions for the development of alternative energy sources: an emphasis on solid biofuels and flexible technologies for its production: a monograph]. Kharkiv: KhNUMG named after OM Beketov, 109-185 [in Ukrainian].

2. Kulyk M.I., Padalka V.V. (2020) Rozvytok bioenerhetyky na osnovi roslynnoho enerhetychnoho resursu (na prykladi Poltavskoi oblasti). Upravlinnia stratehiiamy vyperedzhaiuchoho innovatsiinoho rozvytku: monohrafiia [Development of bioenergy on the basis of plant energy resource (on the example of Poltava region). Management of strategies ahead of innovative development: a monograph]. Sums: Territory [in Ukrainian].
3. Pronko L.M., Kolesnyk T.V. (2011). Umovy ta perspektyvy vyrobnytstva i realizatsii ponovliuvalnykh dzherel enerhii $\vee$ Ukraini. [Conditions and prospects of production and sale of renewable energy sources in Ukraine]. Zbirnyk naukovykh prats VNAU Seriia: Ekonomichni nauky - Collection of scientific works of VNAU Series: Economic sciences 1 (48), 185 [in Ukrainian].

4. Pryshlyak N.V. (2021). Potentsiyni mozhlyvosti vyroshchuvannya bioenerhetychnoyi syrovyny na vyrobnytstvo tverdoho biopalyva. [Potential opportunities for growing bioenergy raw materials for the production of solid biofuels.] Agrosvit. - Agricultural world (1-2), 33-45 [in Ukrainian].

5. Dyrektyva Yevropeiskoho Parlamentu ta rady 2009/28/ ES vid 23 kvitnia 2009 roku pro zaokhochennia do vykorystannia enerhii, vyroblenoi z vidnovliuvalnykh dzherel. [Directive 2009/28 / EC of the European Parliament and of the Council of 23 April 2009 on the promotion of the use of energy from renewable sources.]: Ofitsiinyi visnyk Yevropeiskoho soiuzu - Official Journal of the European Union [in Ukrainian].

6. Humentyk M.YA., Kvak V.M., Zamoys'kyy O.I., ta in. (2015) Vplyv elementiv mekhanizovanoyi tekhnolohiyi vyroshchuvannya na produktyvnist' biomasy miskantusu. [Influence of elements of mechanized cultivation technology on miscanthus biomass productivity]. Visnyk Dnipropetrovs'koho derzhavnoho ahrarno-ekonomichnoho universytetu - Bulletin of Dnipropetrovsk State Agrarian and Economic University, 4, 50-54 [in Ukrainian].

7. Humentyk M.Ya. (2019). Osoblyvosti tekhnolohii zmishanoho vyroshchuvannia bioenerhetychnykh zlakovykh kultur dlia vyrobnytstva biopalyva [Features of technology of mixed cultivation of bioenergy cereals for biofuel production.]. Bioenerhetyka - Bioenergy, 1, 16-18 [in Ukrainian].

8. Caslin, B., Finnan J., Easson L. (2011). Miscanthus best practice guidelines Teagasc: Ecclesville Printing Services, V. 52 p. 91

9. Miskantus v Ukraini: kolektyvna monohrafiia. Kolektyv avtoriv (2019). [Miscanthus in Ukraine: a collective monograph.] K.: TOV TsP «Komprint» [in Ukrainian].

10. Hanzhenko O.M. (2015) Tekhnolohiia vyrobnytstva tverdoho biopalyva z miskantusu. [Miscanthus solid biofuel production technology]. Bioenerhetyka - Bioenergy, 2, 13-17.

11. Doronin V.A., Dryha V.V., Kravchenko YU. A, Doronin V.V. (2018). Sposoby pidvyshchennya vykhodu sadyvnoho materialu miskantusu hihant-s'koho [Methods of increasing the yield of planting material of giant miscanthus] Naukovi pratsi Instytutu bioenerhetychnykh kul'tur i tsukrovykh buryakiv : zb. nauk. prats' / In-t bioenerhet. kul'tur i tsukr. buryakiv, Nats. akad. ahrar. nauk Ukrayiny - Inst. Of Bioenergy. crops and sugar. beets, Nat. acad. agrarian. Sciences of Ukraine. Kyyiv: FOP Korzun D. YU., 26, 11-20 [in Ukrainian]

12. Royik M.V. (2019). Miskantus v Ukrayini : monohrafiya [Miscanthus in Ukraine: monograph]. Kyyiv: FOP Yamchyns'kyy O.V. [in Ukrainian]

13. Royik M.V., Kurylo V.L., Humentyk M.YA (2010). Enerhetychni kul'tury dlya vyrobnytstva biopalyva. [Energy crops for biofuel production].Poltava: Naukovi pratsi Poltavs'koyi derzhavnoyi ahrarnoyi akademiyi Scientific works of Poltava State Agrarian Academy, 7, 12-15 [in Ukrainian]. 
14. Kurylo V.L., Humentyk M.YA., Kvak V.M. (2010) Miskantus - perspektyvna enerhetychna kul'tura dlya vyrobnytstva biopalyva [Miscanthus - a promising energy crop for biofuel production]. Ahrobiolohiya Agrobiology, 4 (80), 62-66 [in Ukrainian].

15. Khivrych O.B., Kurylo V.L., KvakV.M. (2011)Enerhetychni roslyny, yak syrovyna dlya biopalyva [Energy plants as raw materials for biofuels]. Propozytsiya-Proposal, 6, 68 [in Ukrainian].

16. Dospehov, B.A. (1979). Metodika polevogo opyta [Field experiment methodology]. Moskva: Kolos [In Russian].

17. Hanzhenko O.M., Kurylo V.L., Humentyk M.YA., ta in. (2016) Metodychni rekomendatsiyi z tekhnolohiy vyroshchuvannya i pereroblyannya miskantusu hihan$t \cdot s$ 'koho [Guidelines for the technology of cultivation and processing of giant miscanthus]. K.: TOV «TSP «Komprynt» [in Ukrainian].

18. Rakhmetov D.B., Kalens'ka S.M., Fedorchuk M.I., ta in. (2017) Metodychni rekomendatsiyi z optymizatsiyi tekhnolohiyi vyroshchuvannya miskantusu $v$ riznykh hruntovo-klimatychnykh zonakh Ukrayiny. [Methodical recommendations for optimizing the technology of growing miscanthus in different soil and climatic zones of Ukraine]. Vydavnychyy tsentr "Kolos»: DVNZ Khersons'kyy derzhavnyy ahrarnyy universytet - Kolos Publishing House: Kherson State Agrarian University [in Ukrainian].

Дековець В.О., Кулик М.І., Галицька М.А. Біологізація технології вирощування міскантусу гігантського на біопаливо

Нині вивчення шляхів збільшення обсягу біомаси енергетичних культур для біопаливного використання набуває актуального значення, що пов'язують із можливістю отримання додаткової енергії із поновлюваного рослинного ресурсу. Не менш важливим чинником при цьому є екологія довкілля. Адже за вирощування енергокультур необхідно мінімізувати вплив на навколишнє природне середовище та дотримуватися принципу сталості. Саме тому метою нашого дослідження було встановити вплив біологізації вирощування міскантусу гігантського на основі сумісного вирощування з бобовими культурами (без застосування добрив) на врожайність біомаси. Польовий дослід будо закладено та проведено в центральній частин Лісостепу на базі Полтавського державного аграрного університету. Ґрунти дослідної ділянки - чорноземи типові середньогумусні. Методи. Під час проведення досліджень застосовували загальнонаукові та спеціальні методи: стаціонарного польового досліду, аналізу й узагальнення, дисперсійний та кореляційний аналізи. Результати. За результатами багаторічного дослідження встановлено зростання вмісту органічної речовини ґрунту на варіантах сумісного вирощування міскантусу гігантського з бобовими культурами. При цьому депонування карбону в ґрунті варіювало в межах від 1,56 до 3,27\%. Верхня частина орного шару ґрунту містили більший відсоток органічної речовини, нижня - значно менший. Визначено збільшення врожайності зеленої маси (до 52,3 т/га) та сухої біомаси (до 15,6 т/га) за сумісного вирощування трьохрічних рослин міскантусу гігантського 3 люпином багаторіч- ним. Сумісне вирощування міскантусу з конюшинною та люцерною теж збільшувало врожайність, але лише на 0,5 т/га за сухою біомасою. На противагу варіанти міскантусу гігантського із люпином сприяли суттєвому зростанню врожаю на 1,1 т/га більше порівняно із контролем. Встановлено, що вміст органічної речовини в ґрунті має сильний зв'язок із врожайністю сухої біомаси міскантусу гігантського на усіх варіантах досліду за коефіцієнтів кореляції $r \geq 0,7$. Висновки. Отже, застосування сумісного вирощування міскантусу гігантського разом із бобовими культурами сприяє збільшенню органічної речовини в ґрунті за одночасного зростання врожайності біомаси.

Ключові слова: міскантус гігантський, способи вирощування, технологія вирощування, урожайність, біомаса.

Dekovetz V.O., Kulyk M.I., Galytska M.A. Biologization of the technology of growing giant miscantus on biofuels

Purpose. Currently, the study of ways to increase the amount of biomass of energy crops for biofuels is gaining relevance. Which is related to the possibility of obtaining additional energy from renewable plant resources. No less important factor is the ecology of the environment. After all, the cultivation of energy crops must minimize the impact on the environment and adhere to the principle of sustainability. Therefore, the aim of our study was to establish the impact of biologization of giant miscanthus cultivation, based on co-cultivation with legumes (without fertilizers) on biomass yield. The field experiment will be established and conducted in the central part of the ForestSteppe on the basis of Poltava State Agrarian University. The soils of the research area are typical medium humus chernozems.

Methods. During the research general and special methods were used: stationary field experiment, an alysis and generalization, variance and correlation analysis. General and special: stationary field experiment, analysis and generalization, analysis of variance and correlation.

Results. According to the results of many years of research, an increase in the organic matter content of the soil has been established on the options of joint cultivation of giant miscanthus with legumes. The carbon deposition in the soil ranged from 1.56 to $3.27 \%$. The upper part of the arable soil layer contained a higher percentage of organic matter, the lower - much less. An increase in the yield of green mass (up to $52.3 \mathrm{t} / \mathrm{ha}$ ) and dry biomass (up to $15.6 \mathrm{t} / \mathrm{ha}$ ) was determined by joint cultivation of threeyear-old giant miscanthus plants with perennial lupine. Combined cultivation of miscanthus with clover and alfalfa also increased yields, but only by $0.5 \mathrm{t} / \mathrm{ha}$ for dry biomass. In contrast, variants of giant miscanthus with lupine contributed to a significant increase in yield by $1.1 \mathrm{t} / \mathrm{ha}$ more than the control.

Conclusions. It was found that the content of organic matter in the soil has a strong relationship with the yield of dry biomass of giant miscanthus in all variants of the experiment with correlation coefficients $r \geq 0.7$. Thus, the use of co-cultivation of giant miscanthus with legumes contributes to the increase of organic matter in the soil while increasing biomass yields.

Key words: Miscanthus giganteus, methods of cultivation, cultivation technology, yield, biomass. 